\title{
Glacier crippling and the rise of the snowline in western New Guinea (Papua Province, Indonesia) from 1972 to 2000
}

\section{Michael L. Prentice}

Indiana Geological Survey and Department of Geology, Indiana University Bloomington, Indiana, United States

mlprenti@indiana.edu

\section{S. Glidden}

Institute for Earth, Oceans and Space, University of New Hampshire, Durham, United States

\section{Introduction}

Whereas surface temperatures in the tropics $\left(20^{\circ} \mathrm{N}-20^{\circ} \mathrm{S}\right)$ have increased $-0.13^{\circ} \mathrm{C} /$ decade between 1979 and 2005 (Trenberth et al. 2007), the smaller warming of the lower tropical troposphere over this interval, $-0.06^{\circ} \mathrm{C} / \mathrm{decade}$, is within the error of the measurements (Karl et al. 2006). This situation is problematic because it calls into question climate model results that show vertical amplification of tropical surface warming (Karl et al. 2006). More specifically, climate models, with natural and anthropogenic forcing, show a decadal-scale warming trend that increases with elevation in the troposphere. On the other hand, several types of observation in the tropics show less warming aloft than at surface (Karl et al. 2006), though the uncertainties are considerable ( $\mathrm{Fu}$ and Johanson 2005). This uncertainty hinders our understanding of important climate feedback processes, such as water vapour and lapse-rate feedbacks, that contribute significantly to the uncertainty in global climate model predictions of the greenhouse effect. Observations of tropical tropospheric temperature before 1979 are even more uncertain (Gaffen et al. 2000; Lazante et al. 2003, 2006).

Tropical mountain glaciers can supplement the instrumental record of tropical tropospheric climate change because they have receded drastically since the late 1800 s and this recession can be inverted for the climate forcing (Kaser and Osmaston 2002; Hastenrath 2005; Oerlemans 2005; Lemke et al. 2007). Tropical glaciers exist in three widespread regions: the Andes, the East African highlands and western New Guinea. The fact that glaciers nearly everywhere have receded argues that the cause has a global footprint. This favours atmospheric warming as the primary driver (Thompson 2000) because changes in atmospheric moisture are more localised. Evidence supporting this notion comes from Thompson et al. (2002), who, based on ice-core 
data, suggested that glaciers atop Mount Kilimanjaro survived the severe droughts of the Holocene and have not receded in the past 11,000 years. This implies that the recent Kilimanjaro ice loss was due not to drying, but primarily to atmospheric warming. Taylor et al. (2006) suggested that a warming trend has been the primary driver of glacier recession in the Rwenzori Mountains, matching the extent of recession to local meteorological records.

On the other hand, local to regional modelling studies of East African glacier recession indicate that changes in atmospheric moisture content have been the primary driver. For instance, Kruss (1983) and Hastenrath (1984) attributed the glacier recession on Mount Kenya from the end of the 19th century until the early 1960s primarily to a significant decrease in precipitation starting around 1880 . The decrease caused a decrease in both cloudiness and glacier albedo and this, in turn, increased absorption of solar radiation at the glacier surface, which drove up ablation. Hastenrath and Kruss (1992) proposed that continued glacier recession from 1963 until 1987 was mainly caused by an increase in atmospheric humidity that forced more efficient use of available energy to increase melting. More recently, Mölg et al. (2003), Kaser et al. (2004), Cullen et al. (2006), and Mölg et al. (2009) proposed that the 20th century recession of Kilimanjaro's glaciers was driven entirely by decreasing precipitation and atmospheric drying. As part of the proof, Mölg and Hardy (2004), Cullen et al. (2007) and Mölg et al. (2008, 2009) showed, using energy and mass-balance modelling, that the retreat of Kilimanjaro glaciers since 2000 reflects atmospheric aridity and the associated increased receipt of solar radiation.

In the tropical Andes, Francou et al. (2004) showed that the cumulative loss of $-25 \mathrm{~m}$ in water equivalent from Antizana Glacier in Ecuador over the eight-year period from 1995 to 2002 was due to the intensity of El Niño events in this interval. During El Niño events, glacier ablation increased because of atmospheric warming and decreased precipitation. The warming resulted in more of the precipitation being rain. The precipitation decrease accompanied reduced cloud cover and greater solar-radiation receipt at the glacier surface. During La Niña events, the opposite conditions occurred and mass balance increased and remained positive for a few months. This evidence implies that tropical Andean glaciers respond to changes in both air temperature and atmospheric moisture related to the El Niño-Southern Oscillation (ENSO).

Before the availability of mass-balance data, changes in the altitude of the equilibrium line (ELA) of tropical Andean glaciers were used to evaluate climate forcing of glacier recession. Kaser and Osmaston (2002) proposed that the ELA of glaciers in the Cordillera Blanca, Peru, rose $95 \pm 5 \mathrm{~m}$ from the 1920 s to 1970 . Based on modelling and independent climate records, they suggested that the majority of this rise was due to a decrease in atmospheric moisture, with warming playing a small role.

In New Guinea, analysis of the climate forcing of the 20th century glacier recession has been hampered by the lack of field studies on the glaciers, owing to their remoteness and also because of conflicting evidence from studies based on remote sensing. The principal New Guinea ice bodies of the late 20th century are the Carstensz Glaciers in Indonesia (Figure 1). Since the last and only field study of glacier mass balance was conducted in 1971-1973 (Allison 1974, 1976), several estimates of the ELA of the glaciers have been published (Figure 2). Fluctuations in the ELA of a glacier are closely correlated to its mass balance and can be estimated without mass balance data by several means. Van Ufford and Sedgwick (1998) estimated that the ELA of the Carstensz Glaciers increased $60 \pm 10$ m between 1972 and 1995. Klein and Kincaid (2006) estimated that the ELA of the Carstensz Glaciers rose at least $100 \mathrm{~m}$ between 1972 and 2002 (Figure 2). Taken together, these estimates represent a 'low road' ELA scenario. Based on other data, Prentice and Hope (2007) suggested that the ELAs were higher in altitude and rose considerably more from 1972 to 1997 (Figure 2). This constitutes a 'high road' ELA scenario. The purpose of this paper is to present mass-balance data that was the basis for the high-road ELA hypothesis of Prentice and Hope (2007) in the context of glacier recession to 2006. Further resolution of the New Guinea ELA narrative will aid resolution of the regional and, perhaps, global tropical climatic forcing of the retreat of tropical glaciers. 


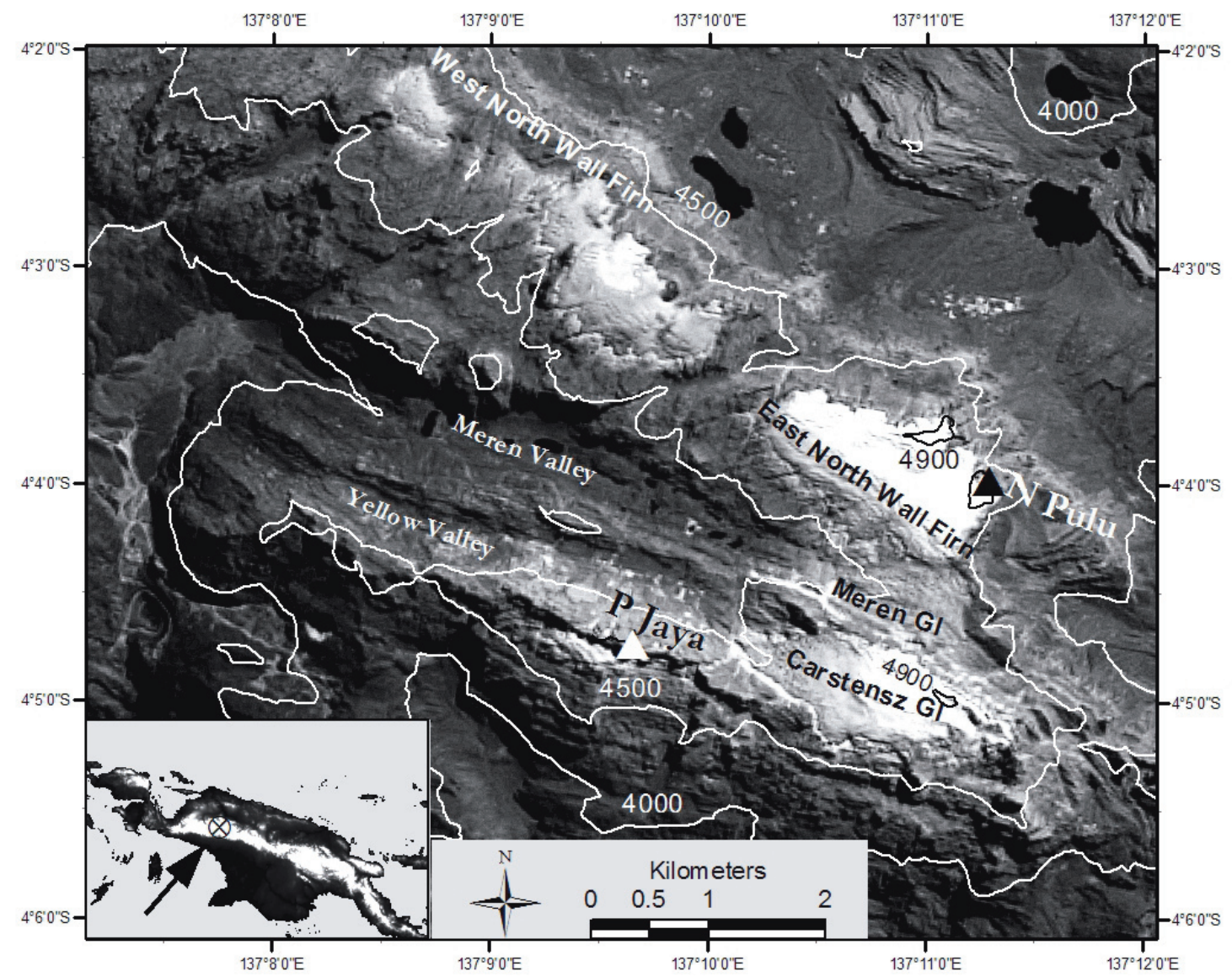

Figure 1. Satellite image of the Carstensz Glaciers, Papua Province, Indonesia, in 1987. Contours are in metres above sea level. The image was taken in July and shows the transient snowline separating snow from firn on the glaciers. The inset shows New Guinea location

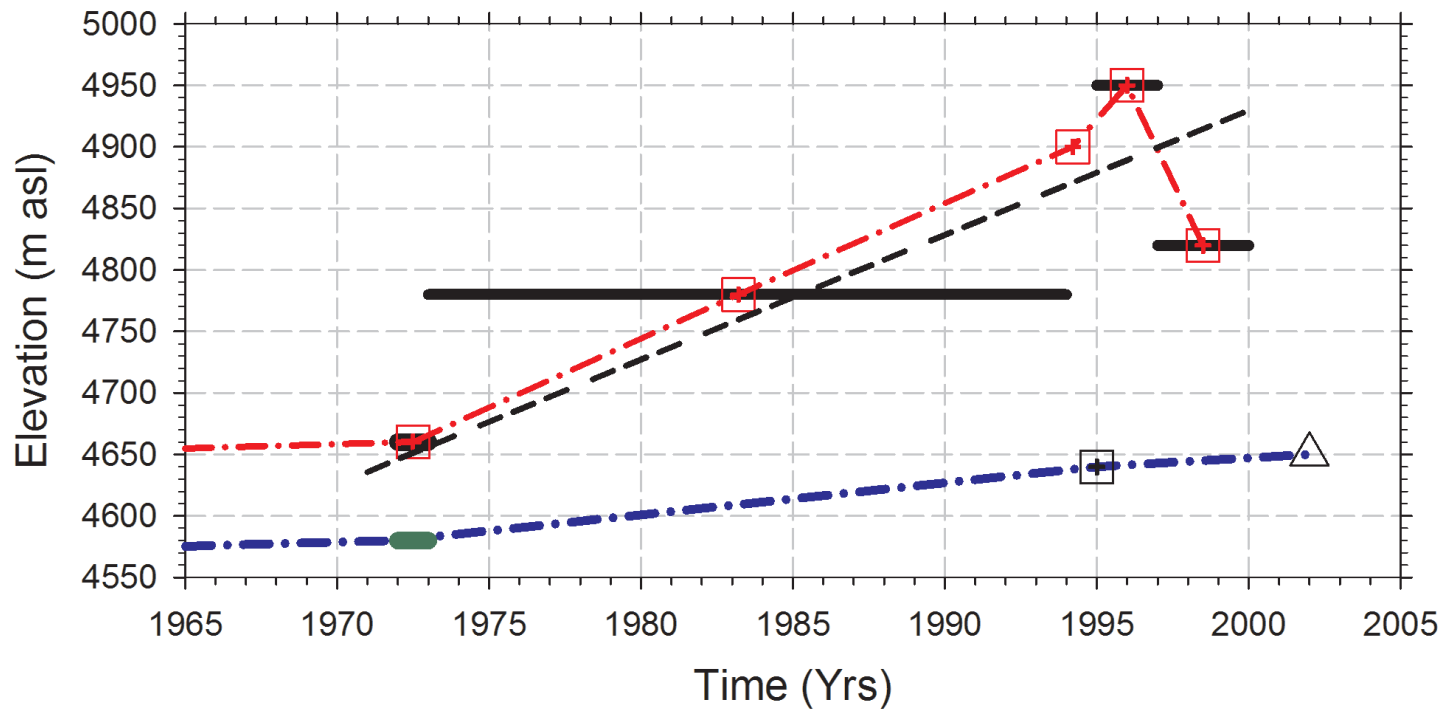

Figure 2. ELA estimates for the Meren Glacier System between 1965 and 2002. Black horizontal lines depict ElAs based on mass balance; their length depicts the mass-balance time interval. The 1972/73 ELA is from Allison (1976), increased by $77 \mathrm{~m}$ as explained in the text; others are from this paper. The green line is the unmodified 1972/73 ELA from Allison. The red squares and dash-dot line show the high-road ELA hypothesis of Prentice and Hope (2007). The blue dash-dot line represents a low-road ELA hypothesis that uses the Van Ufford and Sedgwick (1998) ELA (Đ) and the Klein and Kincaid (2006) minimum ELA for $2002(\Delta)$. The dashed black line shows the high-road ELA trend based on high-road ELAs with that centered on 1972/72, decreased by $30 \mathrm{~m}$ to offset assumed interannual bias in the Allison (1976) value 


\section{New Guinea glacier recession}

At the time of their first survey (Dozy 1938), the Carstensz Glaciers consisted of two valley glaciers, the Meren and Carstensz in the Meren and Yellow valleys, respectively, as well as a plateau glacier, the Northwall Firn (Figure 1). The Northwall Plateau trends northwestsoutheast and, along its northeastern edge, reaches peak elevations of nearly $5000 \mathrm{~m}$ asl. The plateau dips relatively gently to the southwest before dropping off into the Meren Valley. The landmark study of the Carstensz Glaciers was accomplished over the course of two Australian Universities Carstensz Glacier Expeditions (CGE I and II) between December 1971 and February 1973. The results of CGE I and II as well as previous study of the glaciers are detailed in Hope et al. (1976). By the time of the CGE I, the Northwall Firn had separated into western and eastern ice masses. The eastern Northwall Firn (ENWF) provided ice flow to, and so was part of, the Meren Glacier in the Meren Valley.

Glacier positions from 1936 until 1972 were described by Peterson et al. (1973) and Allison (1974). Allison and Peterson (1989) and Peterson and Peterson (1995) further chronicled the recession of the glaciers using 1987 SPOT imagery. Van Ufford and Sedgwick (1998) contributed a map with 1993 glacier boundaries from oblique aerial photography and a few 1994 boundaries from field surveys. Klein and Kincaid (2006) updated the recession of the Carstensz Glaciers to 2002 by contributing ice areas measured on IKONOS satellite images from 2000 and 2002. Prentice and Hope (2007) presented maps of the recession of the Carstensz Glaciers to 2000. Their work was based on orthophotographs of the glaciers in 1995, 1997 and 2000, as well as topographic data supplied by PT Freeport Indonesia (PTFI, Table 1). For their results, Prentice and Hope (2007) transformed all pre-1995 maps to the 1995 basemap.

In this paper, we focus on the Meren Glacier System (MGS), in which we include the Meren Glacier and the ENWF (Figure 3). Until the late 1980s, there were two lobes of the Meren Glacier. The lobe that flowed westward down the Meren Valley is commonly referred to as the Meren Glacier but, in this paper, is referred to as the West Meren Lobe to distinguish it from the eastward-flowing lobe. Hope at al. (1976) produced a topographic map of the MGS with $10 \mathrm{~m}$ contours on the West Meren Lobe and $50 \mathrm{~m}$ contours on the ENWF (Hope et al. 1976). This map is crucial to estimating changes in the ELA since 1972. By the early1990s, the Meren Glacier had effectively separated from the ENWF, which hastened complete melting of the former between 1997 and 2000 (Figure 3). Before summarising the mass-balance data that supports the high-road ELA hypothesis from 1972 to 2000, we update the record of the recession of the MGS to 2006.

\section{Methods}

MGS lengths, areas and front elevations were computed based on a series of digital maps of the glacier boundaries that were derived from the sources listed in Table 1. For 1995, 1997, 2000 and 2006, boundaries of perennial, semi-permanent ice were drawn on the digital orthophotographs provided by PT Freeport Indonesia (PTFI). For 1987, boundaries were drawn using two nearly simultaneous SPOT images that were projected by PTFI. For 1972 , the boundaries were derived from the topographic map of the glaciers and immediate surroundings produced by CGE I and II (Hope et al. 1976) after that map was digitised and transformed to the PTFI 1995 digital topographic basemap.

We calculated the mass balance for the MGS for three periods, 1973/74-1994/95 (hereafter, 1973-1995), 1995/96-1996/97 (i.e. 1995-1997), and 1997/98-1999/00 (i.e. 1997-2000) from DEMs of the MGS and surrounding bedrock, following the method of Østrem and Stanley (1969). Input to the DEMs is listed in Table 2. Surface topography of the MGS for 1995, 1997 and 2000 was provided by PTFI. The topography for 1995 was produced using photogrammetric methods from 1995 aerial photographs with a scale of 1:30,000. 


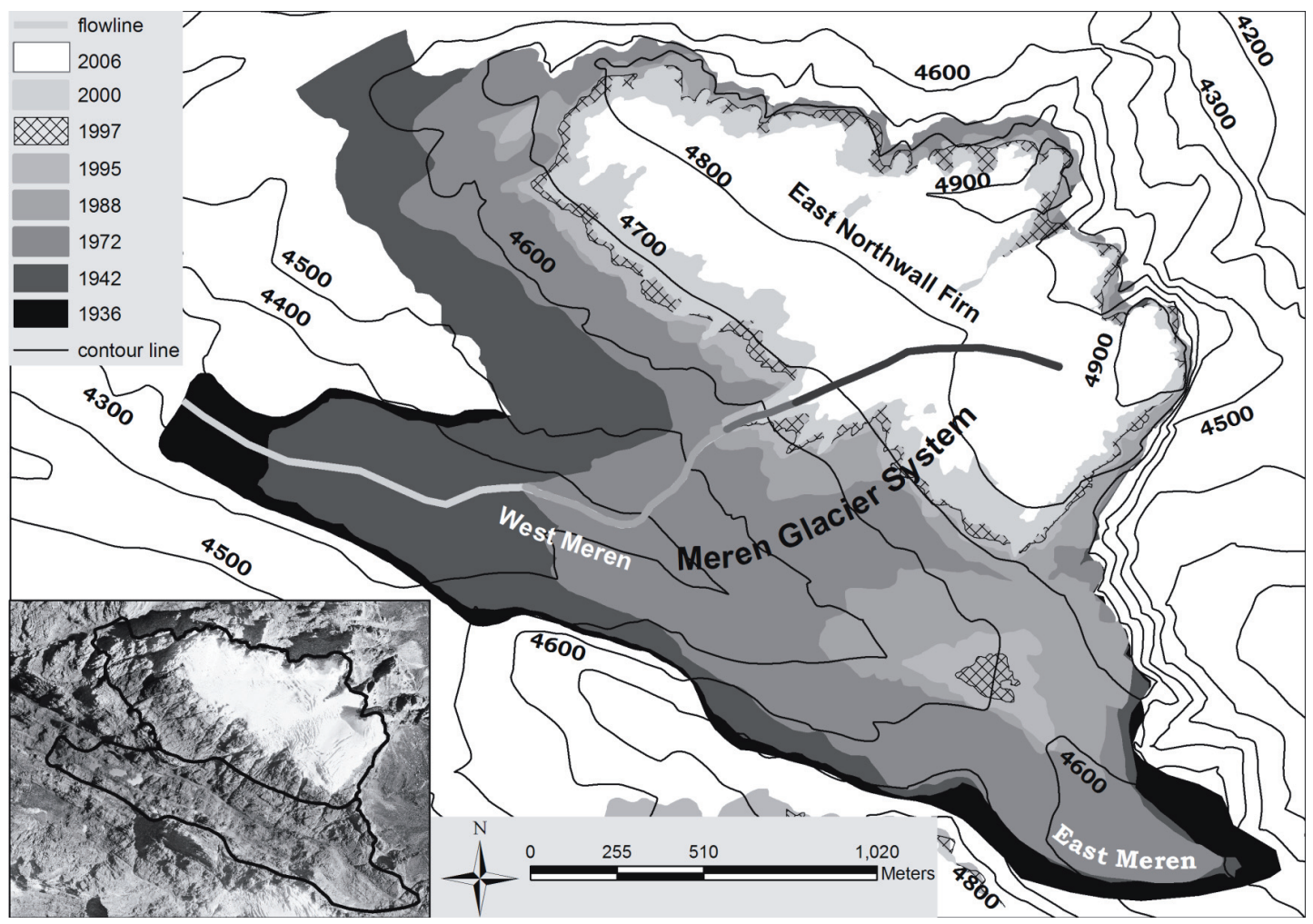

Figure 3. Map of the Meren Glacier System between 1936 and 2006. The inset map shows the 1936 extent on the 2000 orthophotograph. The Meren central flowline is in multiple gray shades. Topography in metres above sea level is for 1995. The East Meren Lobe extent is based on trimlines. Projection is UTM Zone $53 \mathrm{~S}$

Table 1. Sources of glacier boundary information

\begin{tabular}{|c|c|}
\hline Date & Data source \\
\hline 1936 & Peterson and Peterson (1995) \\
\hline 1942 & Peterson and Peterson (1995) \\
\hline 1962 & Peterson and Peterson (1995) \\
\hline Dec,1971-Feb,1973 & Hope et al. 1976 \\
\hline 10-21 July 1987 & SPOT Pan and XS \\
\hline 4 Feb 1995 & PTFI* orthophoto $(1: 30,000)$ \\
\hline 8 May 1997 & PTFI* orthophoto $(1: 25,000)$ \\
\hline 5 Feb 2000 & PTFI* orthophoto $(1: 25,000)$ \\
\hline 6 Apr 2006 & PTFI* orthophoto \\
\hline
\end{tabular}

* PTFI: PT Freeport Indonesia

Table 2. Input to the glacier and bedrock DEMS

\begin{tabular}{|l|l|}
\hline Date & Data source \\
\hline $1972-1973$ & $1972 / 73$ glacier surface elevation increased by $77 \mathrm{~m}, 1972 / 73$ glacier boundary \\
\hline 4 Feb 1995 & 1995 glacier surface elevations, 1995 glacier boundary, 1995 surface topography \\
\hline 8 May 1997 & $\begin{array}{l}1997 \text { glacier surface elevations, } 1995 \text { surface topography decreased by 5-10 m between the } 1995 \text { and } \\
1997 \text { glacier boundaries }\end{array}$ \\
\hline 5 Feb 2000 & $\begin{array}{l}2000 \text { glacier surface elevations, 2000 glacier boundary, } 1995 \text { surface topography decreased by 5-10 } \\
\text { m between the } 1995 \text { and 2000 glacier boundaries }\end{array}$ \\
\hline
\end{tabular}


In order to calculate mass balance for 1995-1997 and 1997-2000, we used an estimate of bedrock topography between the 1995 and 2000 ice limits. This is required in order to estimate ice thickness change outside the MGS boundary at the end of those mass-balance periods. Bedrock topographic contours were inferred in those areas by subtracting 5-10 m from the 1995 MGS surface topography.

We restricted our calculation of mass balance for 1973-1995 to the West Meren Lobe because the surface topography of the ENWF is considered too low in resolution (50 m contours) and accuracy for meaningful results. After transforming the topographic map of Hope et al. (1976) to the 1995 PTFI map, we found that bedrock surfaces were lower than the same surfaces in the 1995 PTFI map by an average of $77 \mathrm{~m}$. Therefore, all 1973 ice elevations were increased by $77 \mathrm{~m}$.

We computed grids of ice thickness change or net specific balance, $b_{n}$ for the three time intervals from the DEMS. We contoured $b_{n}$ at both $5 \mathrm{~m}$ and $10 \mathrm{~m}$ intervals and then converted the areas between the contours into non-overlapping polygons that terminate at the glacier edge. Each polygon was assigned an average $b_{n}$. These polygons were merged with topographic contour lines to produce mass-balance polygons within each contour interval.

We calculated total net mass balance, $B_{n}$, in $\mathrm{m}^{3}$ for each contour interval by multiplying the area of each mass-balance polygon by its average $b_{n}$ and summing across each $10 \mathrm{~m}$ contour interval. Dividing $B_{n}$ by the area of the elevation zone gives average $b_{n}$ for the elevation zone. We added $B_{n}$ for each contour interval to obtain total $B_{n}$ for the entire glacier.

To convert average $b_{n}$ in $m$ to conventional units of $m m$ of water equivalent ( $\mathrm{mm}$ we), we assumed that firn with an average density of $500 \mathrm{~kg} / \mathrm{m}^{3}$ was lost. We converted $B_{n}$ and $b_{n}$ for 1995-2000 into annual budgets by dividing by the number of months in the balance period and then multiplying by 12 . For the 1973-1995 interval, we divided by 22 years to derive an average $\mathrm{B}_{\mathrm{n}}$ and $\mathrm{b}_{\mathrm{n}}$ in $\mathrm{mm} /$ year during that time.

\section{Results}

\section{Glacier length and area changes}

Relative to its length in 1936 established by the Colijn Expedition (Dozy 1938), the length of the MGS system has decreased by 72 per cent from 1936 to 2006 (Figure 4, Table 3). The area of the MGS decreased by 77 per cent between 1942 and 2006 (Figure 4, Table 3). We measured length along a flowline that we infer to be central to and therefore representative of the MGS from 1936 to 2006 (Figure 3). The flowline is anchored at a spot in the northeast sector of the MGS, approximately on top of a persistent ice dome. The flowline bisects the ENWF ice lobe that occupied a shallow channel that connects the Northwall Plateau to the Meren Valley. In the Meren Valley, the flowline turns west and bisects the front of the former West Meren Lobe as it receded from 1936 to 1972. Along this flowline, the MGS front receded $2114 \mathrm{~m}$ up the Meren Valley and the Northwall Plateau.

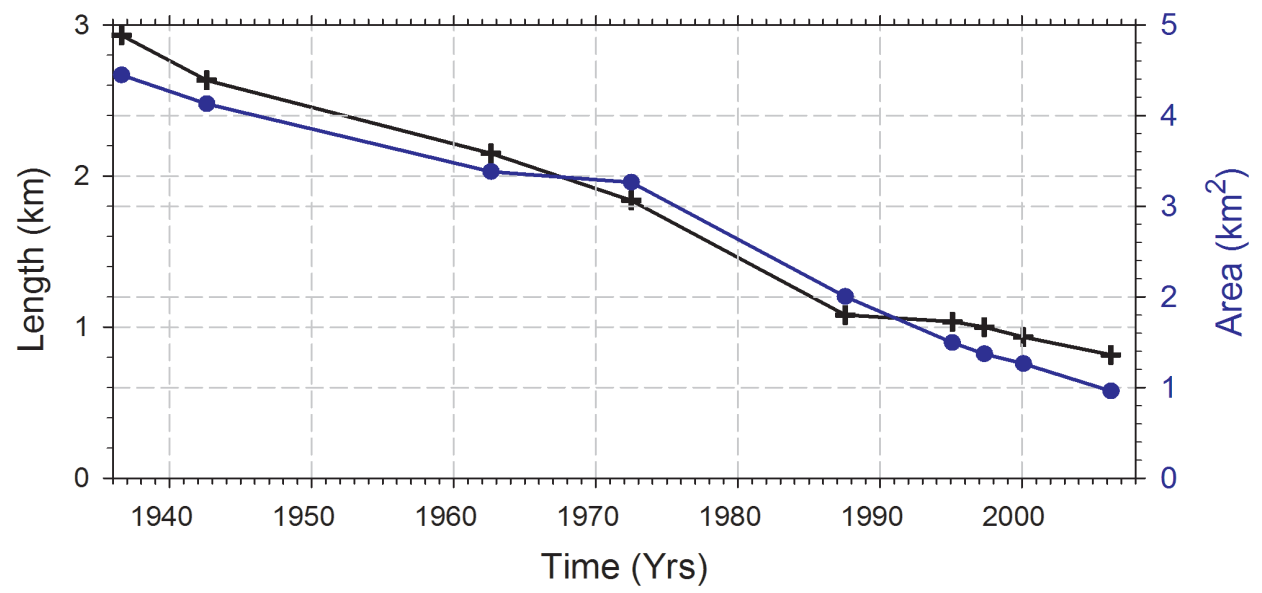

Figure 4. Changes in the length and area (blue dots) of the Meren Glacier System between 1936 and 2006. Length was measured on a map along the central flowline and is not adjusted for slope 
Table 3. Length, area, front elevation and ELA of the Meren Glacier system for 1936-2006

\begin{tabular}{|l|c|c|c|}
\hline Year & MGS length $\mathbf{( m )}$ & MGS area $\left.\mathbf{( k m}^{\mathbf{2}}\right)$ & MGS front elevation (m asl) \\
\hline 1936 & 2931 & & 4305 \\
\hline 1942 & 2633 & 4.13 & 4335 \\
\hline 1962 & 2150 & 3.38 & 4 \\
\hline 1972 & 1838 & 3.26 & 4355 \\
\hline 1987 & 1081 & 2.03 & 4532 \\
\hline 1995 & 1036 & 1.49 & 4540 \\
\hline 1997 & & 1.37 & \\
\hline 2000 & 934 & 1.26 & \\
\hline 2006 & 817 & 0.96 & 4658 \\
\hline
\end{tabular}

Both the rate of ice-front recession and areal shrinkage appear to have been relatively high between 1972 and 1987 (Figure 4). Whereas the length record may reflect the switch of the flowline from the Meren Valley to the steeper-sloped Northwall Plateau, the increased areal loss rate must partially reflect the rapid melting of West Meren Lobe after it separated from the ENWF. The MGS retreat rate was slightly less between 1995 and 2006 than between 1972 and 1987.

\section{Glacier front elevation}

Between 1936 and 2006, the altitude of the retreating MGS front increased by $-350 \mathrm{~m}$ along the central MGS flowline (Figure 5). The big step between 1972 and 1987 in part reflects the steep topography between the 1972 front position, which is in the Meren Valley, and the 1987 position, which is on the Northwall Plateau. Figure 6 also shows the elevation of the front of the West Meren Lobe in the Meren Valley in 1987 and 1995. Regardless of which front is followed, the rate of front altitude increase was higher after 1972 than between 1936 and 1972 , as was the case with glacier area.

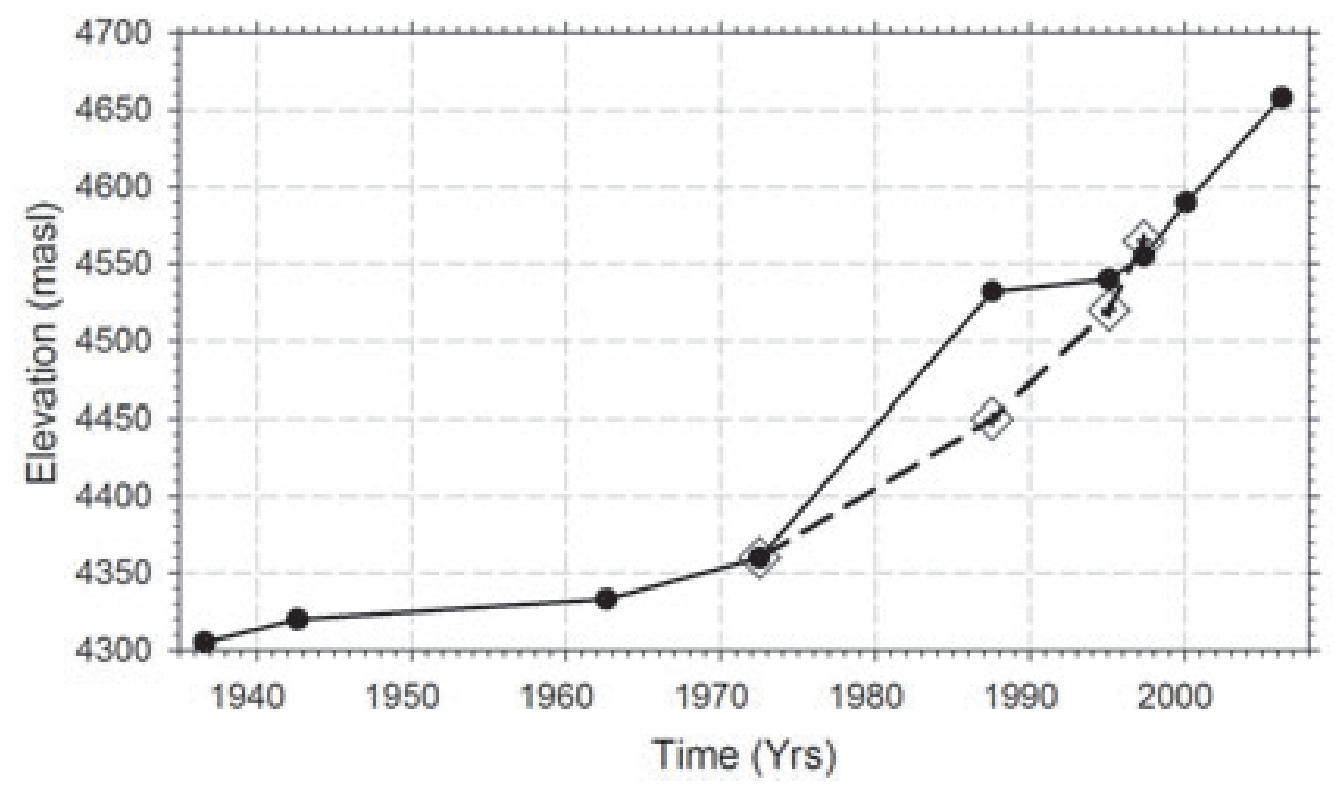

Figure 5. Front elevation of the Meren Glacier System along the central flowline between 1936 and 2006. The dashed line shows the front elevation of the West Meren Lobe in the Meren Valley 


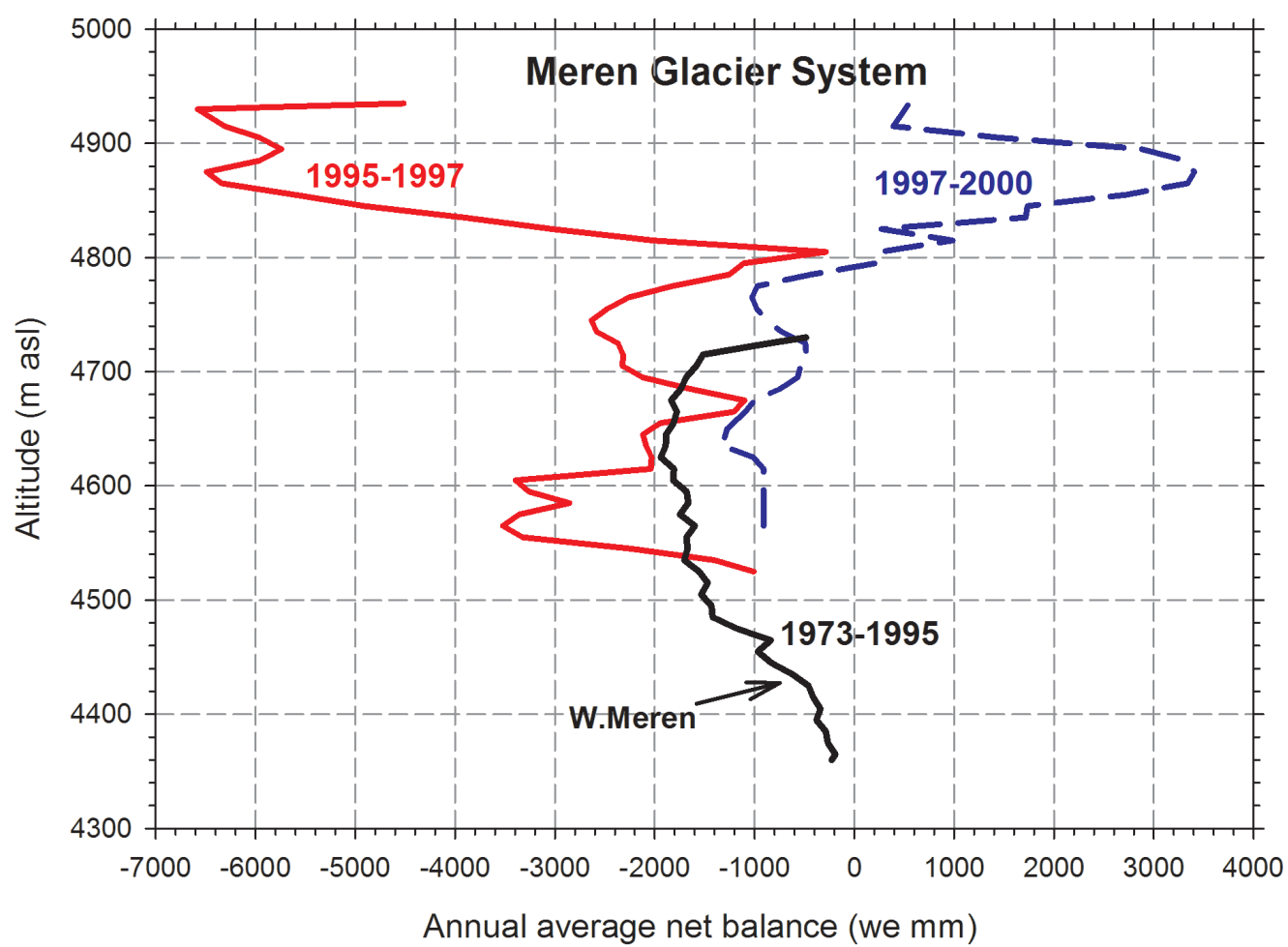

Figure 6. Variation of the annual net specific mass budget of the Meren Glacier System with altitude. The data are annual averages for 1973-1995, 1995-1997 and 1997-2000

Our ice-front elevations are considerably higher than those reported by Klein and Kincaid (2006). They reported that the lower margin of the MGS rose $165 \mathrm{~m}$ from 1972 until 2002. We estimate that the rise over this interval was $230 \mathrm{~m}$.

\section{Glacier mass balance and hypsometry}

The annual specific net balance, $b_{n}$, for the West Meren Lobe over the 22-year interval 19731995 was $-1517 \mathrm{~mm}$ we (Table 4). Figure 6 shows that the entire glacier experienced net melting and that the peak melting rate was $-1900 \mathrm{~mm}$ we/yr at $-4620 \mathrm{~m}$ asl. As much as 130-140 $\mathrm{m}$ of ice thickness were lost from the West Meren Lobe over the entire interval. The annual total budget, $B_{n}$, for the West Meren Lobe over this interval averaged $-1278 \mathrm{x}$ $10^{3} \mathrm{~m}^{3}$ we (Table 4). Variation of annual $B_{n}$ with altitude shows that the volume losses were highest at $-4700 \mathrm{~m}$ asl (Figure 7 ). Though $\mathrm{B}_{\mathrm{n}}$ and $\mathrm{b}_{\mathrm{n}}$ were not calculated for the ENWF over this interval, it is clear from comparison of the hypsometries for the MGS in 1972/73 and in 1994/95 (Figure 8) that a considerable area of ENWF was lost up to an altitude of $4780 \mathrm{~m}$ asl, above which there does not appear to have been much loss.

Table 4. Annual average total balance and specific net balance for the Meren Glacier system: 1971-2000

\begin{tabular}{|l|c|c|c|c|c|c|c|}
\hline & \multicolumn{2}{|l|}{ East Northwall Firn } & \multicolumn{2}{l|}{ West Meren Lobe } & \multicolumn{2}{l|}{ Meren Glacier System } \\
\hline Balance Yr & $\begin{array}{c}\mathrm{B}_{\mathrm{n}^{3}} \\
\left(10^{3} \mathrm{~m}^{3} \mathrm{we}\right. \\
\left./ \mathrm{yr}^{*}\right)\end{array}$ & $\begin{array}{c}\mathrm{b}_{\mathrm{n}} \\
(\mathrm{mm} \text { we/yr })\end{array}$ & $\begin{array}{c}\mathrm{B}_{\mathrm{n}} \\
\left(10^{3} \mathrm{~m}^{3} \mathrm{we} /\right. \\
\left.\mathrm{yr}^{*}\right)\end{array}$ & $\begin{array}{c}\mathrm{b}_{\mathrm{n}} \\
(\mathrm{mm} \text { we/yr })\end{array}$ & $\begin{array}{c}\mathrm{B}_{\mathrm{n}} \\
\left(10^{3} \mathrm{~m}^{3} \mathrm{we}_{\mathrm{yr}}^{*}\right)\end{array}$ & $\begin{array}{c}\mathrm{b}_{\mathrm{n}} \\
(\mathrm{mm} \text { we/yr })\end{array}$ & $\begin{array}{c}\text { Average ELA } \\
(\mathrm{m} \text { asl })\end{array}$ \\
\hline $1972 / 73$ & & & $-990 \#$ & $-510 \#$ & $-57 \#$ & $-60 \#$ & $4657 \dagger$ \\
\hline $1973-1995$ & & & -1278 & -1517 & & & 4780 \\
\hline $1995-1997$ & -4213 & -2999 & -218 & -3298 & $-4,430$ & -3012 & -4950 \\
\hline $1997-2000$ & 452 & 336 & $--8^{\wedge}$ & $--545^{\wedge}$ & 452 & 336 & 4820 \\
\hline
\end{tabular}

* Assumes that the snow and ice has an average density of $500 \mathrm{~kg} / \mathrm{m}^{3}$

\# Mass budgets measured between 1971 and 1973 by CGE I and II (Allison, 1976)

$\dagger$ From Allison (1976) increased by $77 \mathrm{~m}$ as explained in text

$\wedge$ Assumes average thickness of $3 \mathrm{~m}$ in May 1997 and that ice loss spanned 33 months 


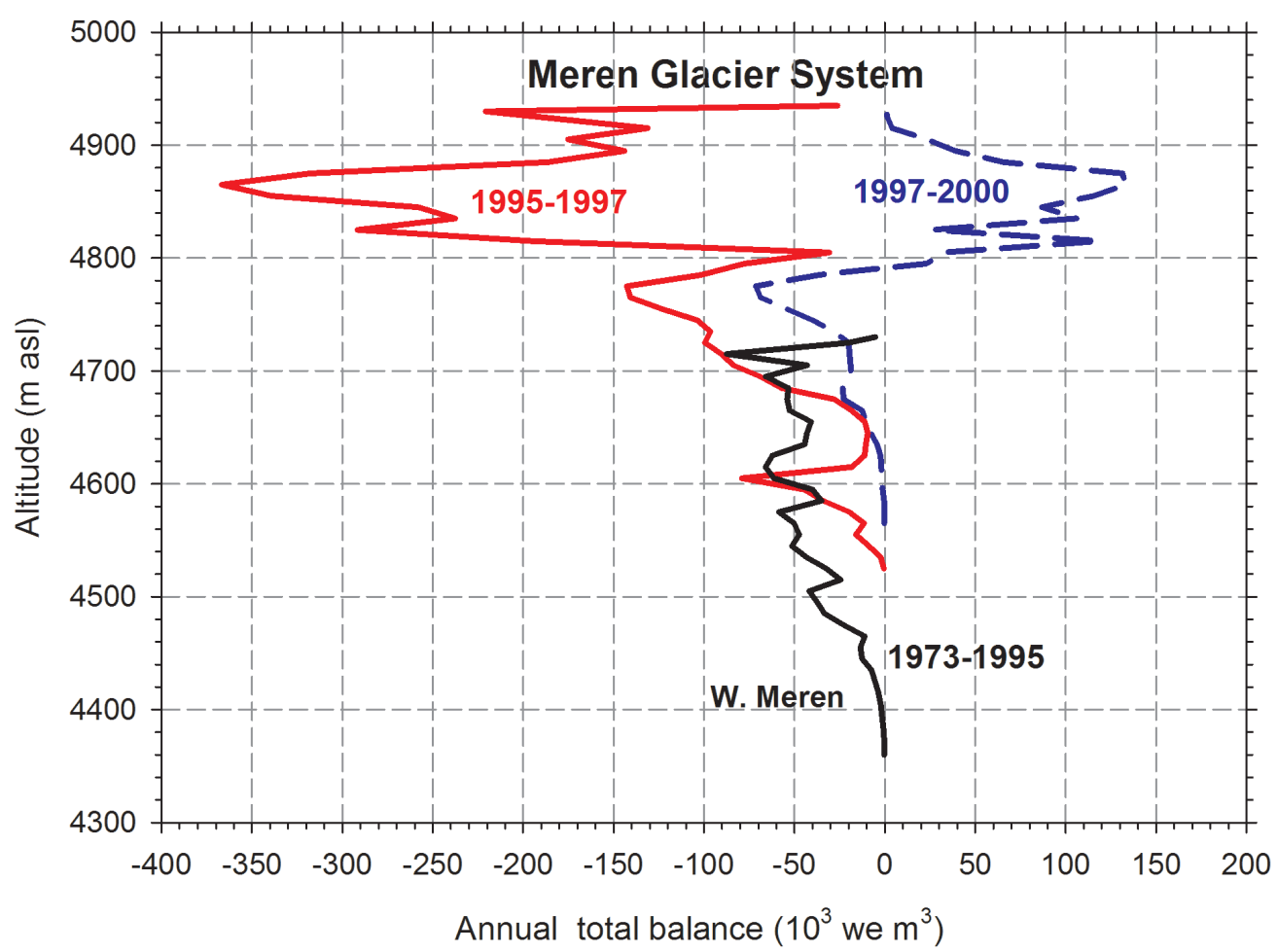

Figure 7. Variation of the annual total mass budget of the Meren Glacier System with altitude. The data are annual averages for 1973-1995, 1995-1997 and 1997-2000

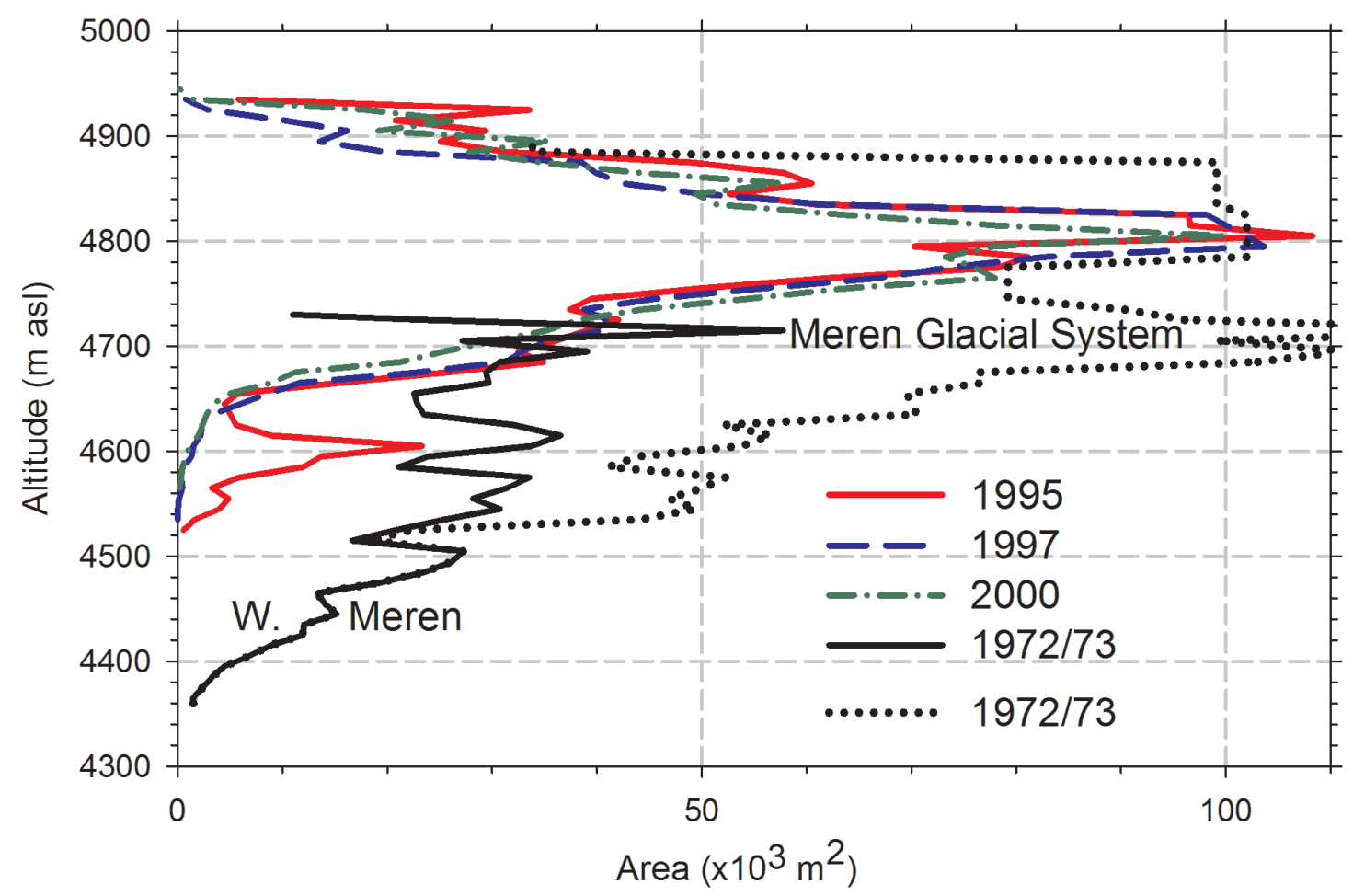

Figure 8. Hypsometry of the Meren Glacier System between 1972 and 2000. For 1972/73, the hypsometries of the West Meren Lobe and the entire MGS are shown with solid line and dotted lines, respectively 
The annual $b_{n}$ for the MGS over the 2.25 year interval 1995-1997 averaged -3012 mm we (Table 4), which is quite negative. The entire MGS had a negative mass budget, with melting rates peaking at more than $6 \mathrm{~m}$ we/yr at $-4900 \mathrm{~m}$ asl (Figures 6,7). The net budget was dominated by losses from the ENWF, though there is a secondary $B_{n}$ peak at $4600 \mathrm{~m}$ asl that represents the deflating West Meren Lobe (Figure 7).

In a significant turn-around, the annual $b_{n}$ for the MGS over the 2.75-year interval 19972000 averaged $+336 \mathrm{~mm}$ we (Table 4). Annual average $b_{n}$ was negative in all elevation zones below $4800 \mathrm{~m}$ asl but positive above this elevation (Figure 6). It was between May 1997 and February 2000 that the West Meren Lobe completely disintegrated but its contributions to the budget are negligible. The greatest mass loss occurred between altitudes of $4860 \mathrm{~m}$ and $4940 \mathrm{~m}$ asl.

\section{Glacier ELA}

The aforementioned mass-balance data provide the basis for inferring the average ELA for the three time intervals of interest and were used to generate the Prentice and Hope (2007) hypothesis (Figure 2). For 1995-1997, we infer that the average ELA was above $4940 \mathrm{~m}$ asl, the highest point on the MGS, and arbitrarily choose $4950 \mathrm{~m}$ asl as a convenient value above $4940 \mathrm{~m}$ (Table 4). For 1997-2000, we suggest that the ELA averaged $4820 \mathrm{~m}$ asl because $b_{n}$ is significantly positive above this altitude (Figure 6).

Allison (1974) determined that the ELA of the MGS for 1972/73 was at $4580 \mathrm{~m}$ asl. Given the 77 m offset mentioned above between the 1972 Hope et al. (1976) and the 1995 PTFI basemaps, we estimate that the 1972/73 ELA is actually at $4657 \mathrm{~m}$ asl.

We suggest that the average ELA for the 22-year interval 1973-1995 was at $4780 \mathrm{~m}$ asl. This is based on the hypsometry (Figure 8 ) and mass-balance information that indicate net melting below and net accumulation above this altitude. Given this information, the 1972/73 ELA at $4657 \mathrm{~m}$ asl, and also that the 1995-97 ELA was above $4940 \mathrm{~m}$ asl, we suggest that, on average, the annual ELA rose over the 22-year interval. The simplest hypothesis is a linear rise in the annual ELA that started at $4657 \mathrm{~m}$ asl, the 1972/73 ELA, and passed through $4780 \mathrm{~m}$ asl, the ELA for the 22-year interval, in 1983, the midpoint of the interval. This hypothesis projects the annual ELA for 1994/1995 to be at $4900 \mathrm{~m}$ asl. We stress that the annual ELA for 1994/95 could have been lower or higher than $4900 \mathrm{~m}$ asl.

Prentice and Hope (2007) estimated that, in 1942, the ELA was at $4639 \pm 10 \mathrm{~m}$ asl, based on Allison and Kruss (1977), who used a 1-D flowline glacier model to constrain the rate of the rise in the ELA before 1972.

\section{Discussion}

Based on area and ice-front elevation, it is clear that the Meren Glacier System was crippled by climate change between 1972 and 1995. In order to sort out the climatic causes of the drastic ice loss, it is essential to sort out the few clues available for the mass balance and ELA narratives. We focus here on the ELA record because it is related to mass balance but, additionally, captures the elevational component of glacier change. Besides, there are various published estimates for the ELA based on independent data. We first examine how the massbalance-based ELAs proposed by Prentice and Hope (2007) and supplemented here compare with other published estimates.

Our hypothesis places the average ELA for the 2.25-year interval 1995-1997 at or above $4950 \mathrm{~m}$ asl, which is about $300 \mathrm{~m}$ above the 1994/95 ELA proposed by Van Ufford and Sedgwick (1998) (Figure 2). Van Ufford and Sedgwick (1998) observed a snowline on the Northwall Firn in May of 1995 at $4640 \pm 10 \mathrm{~m}$ asl and inferred that it was a good approximation for the annual ELA. This observation corresponds temporally to the first few months of our 
2.25-year interval. Whereas $300 \mathrm{~m}$ vertical variation in the transient (daily) ELA is plausible, $300 \mathrm{~m}$ variation in the annual ELA over at most 2.25 years is unlikely. It would require an extreme climate change and none are apparent in local to regional climate records. The time interval in question is between the major El Niño events of 1992/93 and 1997/98. Even if the Van Ufford and Sedgwick estimate was shifted upwards by $77 \mathrm{~m}$, the offset between the Hope et al. (1976) and the PTFI 1995 maps, we suggest that the resulting value, $4720 \mathrm{~m}$ asl, is still incompatible with our 2.25-year mean ELA.

Another way to evaluate the Van Ufford and Sedgwick estimate is to assume that our 19951997 high ELA is incorrect and ask whether our average ELA for 1973-1995 is compatible with the Van Ufford and Sedgwick estimate. It does not appear so for the following reason. The length, area and ice-front elevation retreat records all show continuous retreat (Figures 4, 5). The balance-based ELA for 1973-1995, $4780 \mathrm{~m}$ asl, is higher than the adjusted estimate of Van Ufford and Sedgwick, which means that, if both are considered, then the ELA decreased in elevation by at least $40 \mathrm{~m}$ at some point between 1973 and early 1995. This would be a minimum because the ELA for a considerable portion of the 22-year interval must have been above $4780 \mathrm{~m}$ asl in order to generate an interval mean of $4780 \mathrm{~m}$ asl. The lowering required by this scenario does not agree with continuous ice retreat through the interval. In sum, the Van Ufford and Sedgwick ELA is not compatible with either of our mass-balance-based ELAs.

So how should we regard the Van Ufford and Sedgwick (1998) ELA? Our best interpretation is that it should be increased by $77 \mathrm{~m}$ and considered as a transient, multi-monthly snowline, but not an annual ELA. If this is correct, it implies that there is significant interannual variability in the ELA of the MGS and, thereby, also the Carstensz Glaciers. This seems reasonable given the significant variability in the monthly mass balance of the single intensely studied tropical glacier on the eastern side of the Pacific, Antizana in Ecuador (Francou et al. 2004). In the Ecuadoran case, the monthly variability translated into $290 \mathrm{~m}$ of variation (4 sigma) in the annual ELA between 1994 and 2005 (Haeberli et al. 2007). If interannual ELA variability is indeed significant in western New Guinea, then it is complex to analyse decadal ELA trends using ELAs that are themselves based on widely varying time intervals.

Based on analysis of IKONOS satellite images from 2000 and 2002, as well as a DEM based on data from the Shuttle Radar Topography Mission (SRTM), Klein and Kincaid (2006) suggested that the ELA for the Carstensz Glaciers as a group rose about $100 \mathrm{~m}$ from 1972 to 2000. This would put the absolute value of the ELA, according to Klein and Kincaid (2006), at $4680 \mathrm{~m}$ asl using SRTM topography. This number is too low to be compatible with our ELA estimates for the same reasons described above regarding the Van Ufford and Sedgwick ELA estimate.

If the Klein and Kincaid (2006) ELA estimate is increased by $77 \mathrm{~m}$, the resulting value, $4740 \mathrm{~m}$ asl, fits our ELA narrative better. However, the adjusted Klein and Kincaid value is still lower than our ELA estimate for the 2.75-year interval between 1997 and 2000, implying further lowering of the ELA after 1997-2000. This is somewhat at odds with continued retreat of the MGS as referred to above. Klein and Kincaid did suggest that their ELA estimate represents a minimum value and this seems to be the best interpretation.

Our own hypothesis calls for more than 100 m of ELA lowering between 1995-1997 and 1997-2000 (Figure 2). Because the 1997-2000 ELA is based on a 2.75-year mass balance, the ELA of $4820 \mathrm{~m}$ asl cannot be considered as an interannual extreme. As with the other estimates discussed above, this lowering is also at odds with the records of continuous ice retreat in this interval. However, in this case, we side with the ELA lowering primarily because it is based on a mass-balance calculation. It appears as if the increase in mass occurred between the altitudes of $4840 \mathrm{~m}$ and $4900 \mathrm{~m}$ asl in the eastern half of the MGS (Figures 3, 7). This is well above the ice front along our designated flowline, which was then at $-4590 \mathrm{~m}$ asl. Much of the ice between those elevations could have been stagnant so that they were effectively decoupled. 
We close with an assessment of the trend in the ELA for the MGS between 1970 and 2000. Given the potential for significant interannual variability in the ELA, ELAs used to assess decadal trends should be based on mass balances that cover at least two years, though an average ENSO cycle is preferable. In this regard, the 1972/73 ELA is probably high relative to a multi-year ELA centered on 1972/73. This is because 1972/73 coincided with a large El Niño event which put western New Guinea in an extreme drought. For the sake of discussion, we suggest that the multi-year ELA centered on $1972 / 73$ was $30 \mathrm{~m}$ below $4657 \mathrm{~m}$, at, say $-4625 \mathrm{~m}$ asl. With this value as the starting point, we suggest that the MGS ELA rose at $\sim 100$ m per decade between 1970 and 2000, 294 m total (Figure 2).

\section{Conclusions}

1) From 1936 to 2006, the area of the Meren Glacial System (MGS) decreased by 78 per cent, while the length of a prominent flowline decreased by 72 per cent. Of this ice loss, 66 per cent of the area was lost since 1972/73. The elevation of the MGS snout rose $353 \mathrm{~m}$ between 1936 and 2006, with 84 per cent of this rise coming after 1972.

2) Based on the photogrammetry method, we estimate the specific mass balance of the MGS for 1995-1997 (2.25 years) and 1997-2000 (2.75 years) at $-3012 \mathrm{~mm} \mathrm{we} / \mathrm{yr}$ and $+336 \mathrm{~mm}$ we/yr, respectively. For the 22-year period 1973-1995, we estimate the specific mass balance of the West Meren Lobe of the MGS at $-1517 \mathrm{~mm}$ we/yr.

3) The ELA of the MGS rose -100 m per decade between 1970 and 2000. For 1995-1997, the average ELA was above the highest part of the MGS and we estimate it at $4950 \mathrm{~m}$ asl. For 19972000, the average ELA was $4820 \mathrm{~m}$ asl. For 1973 to 1995, the ELA averaged $4780 \mathrm{~m}$ asl.

\section{Acknowledgements}

We thank PT Freeport Indonesia for topographic data as well as imagery of the glaciers. Dr D. Susanto provided the 2006 image. The work was partially funded by PTFI and the National Science Foundation, Paleoclimate Program. We thank two anonymous reviewers for thoughtful comments that improved the manuscript. Professor Geoffrey Hope has been the principal catalyst for our investigation of New Guinea glaciation and climate history and for that we are grateful. Without Geoff, our involvement would not have happened. By virtue of his interdisciplinary approach, Geoff recognised the importance of understanding New Guinea glaciation for an appreciation of climate and cultural change. Geoff's spirit, generosity and friendship have made our New Guinea-related work highly rewarding.

\section{References}

Allison, I. 1974. Morphology and dynamics of the tropical glaciers of Irian Jaya: Zeitschrift fur Gletscherkunde und Glazialgeologie 10:129-152.

Allison, I. 1976. Glacier regimes and dynamics. In G.S. Hope, J.A. Peterson, U. Radok and I. Allison (eds) The Equatorial Glaciers of New Guinea, pp39-59. Rotterdam: A.A. Balkema. Allison, I., and Peterson, J.A. 1976. Ice areas on Mt. Jaya: Their extent and recent history, In G.S. Hope, J.A. Peterson, U. Radok and I. Allison (eds) The Equatorial Glaciers of New Guinea, pp27-38. Rotterdam: A.A. Balkema. 
Allison, I. and J.A. Peterson 1989. Glaciers of Irian Jaya, Indonesia In R. Williams and J., Ferrigno (eds) United States Geological Survey Professional Paper 1386-H, pp1-20. Washington, DC, U.S.: Government Printing Office.

Cullen, N.J., T. Mölg, G. Kaser, K. Hussein, K. Steffen and D.R. Hardy 2006. Kilimanjaro Glaciers: Recentarealextentfromsatellitedataand newinterpretationofobserved 20thcentury retreat rates. Geophysical Research Letters 33, L16502, doi:10.1029/2006GL027084.

Cullen, N.J., T. Mölg, G. Kaser, K. Steffen and D.R. Hardy 2007. Energy-balance model validation on the top of Kilimanjaro, Tanzania, using eddy covariance data: Annals of Glaciology 46:227-233.

Dozy, J.J. 1938. Eine gletscherwelt in Niederlandisch Neuguinea: Zeitschrift für Gletscherkunde 26:45-51.

Francou, B., M. Vuille, V. Favier and B. Cáceres 2004. New evidence for an ENSO impact on low-latitude glaciers: Antizana 15, Andes of Ecuador, $0^{\circ} 28^{\prime} \mathrm{S}$. Journal of Geophysical Research 109, D18106, doi:10.1029/2003JD004484.

$\mathrm{Fu}$, Q. and C.M. Johanson 2005. Satellite-derived vertical dependence of tropical tropospheric temperature trends. Geophysical Research Letters 32, L10703, doi:10.1029/2004GL022266.

Gaffen, D.J., B.D. Santer, J.S. Boyle, J.R. Christy, N.E. Graham and R.J. Ross 2000. Multidecadal changes in the vertical structure of the tropical troposphere. Science 287:1242-1245.

Georges, C. 2004. The 20th century glacier fluctuations in the Cordillera Blanca (Peru). Arctic, Antarctic, and Alpine Research 36:100-107.

Haeberli, W., M. Hoelzle and M. Zemp 2007. Glacier Mass Balance Bulletin. No. 9 (20042005), p100. Zurich: Staffel Druck AG.

Hastenrath, S. 1984. The Glaciers of Equatorial East Africa. 353p. Dordrecht: Reidel.

Hastenrath, S. 2005. The glaciers of Mt. Kenya 1899-2004. Erdkunde 59:120-125.

Hastenrath, S. and A. Ames 1995. Recession of Yanamarey Glacier in Cordillera Blanca, Peru, during the 20th century. Journal of Glaciology 41:191-196.

Hastenrath, S. and P.D. Kruss 1992. The dramatic retreat of Mount Kenya's glaciers between 1963 and 1987: greenhouse forcing. Annals of Glaciology 16:127-133.

Hastenrath, S. and D. Polzin 2004. Volume decrease of Lewis Glacier, Mount Kenya, 19782004. Zeitschrift für Gletscherkunde und Glazialgeologie 39:133-139.

Hope, G.S., J.A. Peterson, U. Radok and I. Allison 1976. The Equatorial Glaciers of New Guinea. 244p. Rotterdam: A. A. Balkema.

Karl, T.R., S.J. Hassol, C.D. Miller and W.L. Murray 2006. Temperature Trends in the Lower Atmosphere: Steps for Understanding and Reconciling Differences. A Report by the Climate Change Science Program and the Subcommittee on Global Change Research: Washington, DC.

Kaser, G., D.R. Hardy, T. Mölg, R.S. Bradley and T.M. Hyera 2004. Modern glacier retreat on Kilimanjaro as evidence of climate change: observations and facts. International Journal of Climatology 24:329-339.

Kaser, G. and H.A. Osmaston 2002. Tropical Glaciers. 207p. Cambridge: Cambridge University Press.

Klein, A.G. and J.L. Kincaid 2006. Retreat of glaciers on the Puncak Jaya, Irian Jaya, determined from 2000 and 2002 IKONOS satellite images. Journal of Glaciology 52:65-79.

Kruss, P.D. 1983. Climate change in East Africa: a numerical simulation from the 100 years of terminus record at Lewis Glacier, Mount Kenya. Zeitschrift für Gletscherkunde und Glazialgeologie 19:43-60.

Lanzante, J.R., S.A. Klein and D.J. Seidel 2003. Temporal homogenization of monthly radiosonde temperature data. Part II: trends, sensitivities, and MSU comparison. Journal of Climate 16:241-262. 
Lanzante, J.R., T.C. Peterson, F.J. Wentz and K.Y. Vinnikov 2006. What do observations indicate about the change of temperatures in the atmosphere and at the surface since the advent of measuring temperatures vertically?. In T.R. Karl, S.J. Hassol, C.D. Miller and W.L. Murray (eds) Temperature Trends in the Lower Atmosphere: Steps for Understanding and Reconciling Differences. pp47-70. A Report by the Climate Change Science Program and the Subcommittee on Global Change Research, Washington, DC.

Lemke, P., J. Ren, R.B. Alley, I. Allison, J. Carrasco, G. Flato, Y. Fujii, G. Kaser, P. Mote, R.H. Thomas and T. Zhang 2007. Observations: Changes in snow, ice, and frozen ground. In S. Solomon, D. Quin, M. Manning, Z. Chen, M. Marquis, K.B. Averyt, M. Tignor and H.L. Miller (eds) Climate Change 2007: The Physical Science Basis. Contribution of Working Group 1 to the Fourth Assessment Report of the Intergovernmental Panel on Climate Change. pp337-377. Cambridge, United Kingdom: Cambridge University Press.

Mölg, T., N.J. Cullen, D.R. Hardy, G. Kaser and E.J. Klok 2008. Mass balance of a slope glacier on Kilimanjaro and its sensitivity to climate. International Journal of Climatology 28:881-892.

Mölg, T., N.J. Cullen and G. Kaser 2009. Quantifying climate change in the tropical midtroposphere over East Africa from glacier shrinkage on Kilimanjaro. Journal of Climate 22:4162-4181.

Mölg, T., C. Georges and G. Kaser 2003. Solar-radiation-maintained glacier recession on Kilimanjaro drawn from combined ice-radiation geometry modeling. Journal of Geophysical Research 108, doi:10.1029/2003JD003546.

Mölg, T. and D.R. Hardy 2004. Ablation and associated energy balance of a horizontal glacier surface on Kilimanjaro. Journal of Geophysical Reasearch 109, doi:10.1029/2003JD004338.

Oerlemans, J. 2005. Extracting a climate signal from 169 glacier records. Science 308:675677.

Østrem, G. and A. Stanley, 1969. Glacier Mass Balance Measurements, A Manual for Field and Office Work. p111. Oslo: Canadian Department of Energy, Mines, and Resources and Norwegian Water Resources and Electricity Board.

Peterson, J.A., G.S. Hope and R. Mitton 1973. Recession of snow and ice fields of Irian Jaya, Republic of Indonesia. Zeitschrift für Gletscherkunde und Glazialgeologie 9:73-87.

Peterson, J.A. and L.F. Peterson 1995. Ice retreat from the Neoglacial Maximum in the Puncak Jaya kusuma region, Republic of Indonesia. Zeitschrift für Gletscherkunde und Glazialgeologie 30:2.

Prentice, M.L. and G.S. Hope 2007. Climate of Papua and its recent changes. In A.J. Marshall and B.M. Beehler (eds) The Ecology of Papua, pp177-195. Singapore: Periplus Editions.

Taylor, R.G., L. Mileham, C. Tindimugaya, A. Majugu, A. Muwanga and B. Nakileza 2006. Recent glacial recession in the Rwenzori Mountains of East Africa due to rising air temperature. Geophysical Research Letters 33:L10402, doi:10.1029/2006GL025962.

Thompson, L.G. 2000. Ice core evidence for climate change in the Tropics: implications for our future. Quaternary Science Reviews 19:19-35.

Thompson, L.G., E. Mosley-Thompson, M.E. Davis, K.A. Henderson, H.H. Brecher, V.N. Zagorodnov, D.R. Hardy and J. Beer 2002. Kilimanjaro ice core records: Evidence of Holocene climate change in tropical Africa. Science 298:589-593.

Trenberth, K.E. 1990. Recent observed interdecadal climate changes in the northern hemisphere Bulletin of the American Meteorological Society 71:988-993. 
Trenberth, K.E., P.D. Jones, P. Ambenje, R. Bojariu, D. Easterling, A. Klein Tank, D. Parker, F. Rahimzadeh, J.A. Renwick, M. Rusticucci, B. Soden and P. Zhai 2007. Observations: Surface and atmospheric climate change In S. Solomon, D. Quin, M. Manning, Z. Chen, M. Marquis, K.B. Averyt, M. Tignor and H.L. Miller (eds) Climate Change 2007: The Physical Science Basis. Contribution of Working Group 1 to the Fourth Assessment Report of the Intergovernmental Panel on Climate Change, pp235-335. Cambridge, United Kingdom and New York City, NY, USA: Cambridge University Press.

Van Ufford, A.Q. and P. Sedgwick 1998. Recession of the equatorial Puncak Jaya glaciers ( 1985 to 1995), Irian Jaya (western New Guinea), Indonesia. Zeitschrift für Gletscherkunde und Glazialgeologie 34:131-14. 